\title{
Revisiting civil society in Turkey
}

\author{
Metin Heper* and Senem Yildırım \\ Department of Political Science, Bilkent University, Ankara, Turkey
}

(Final version received 26 May 2010)

\begin{abstract}
In studies on civil society, there is a tendency to perceive it as an instrument for the transition from an authoritarian system of government to a democratic one. It is not taken as a societal entity in an already consolidated democracy that contributes to the making of public policies. This is also the case when it comes to studies on civil society in Turkey. Assuming that Turkey has a consolidated democracy, this article investigates the extent to which one comes across impediments to, prerequisites of, and the primary characteristics of civil society in this country. It arrives at the conclusion that at least in the Turkish case, one may not talk about the presence or absence of civil society; one may come across only some of its characteristics and not others.
\end{abstract}

Keywords: transition to democracy; consolidated democracy; contribution to policy-making; civil society; Turkey

In the literature on the relationship between civil society and democracy, the question of which is a prerequisite and which is a consequence has not been resolved, though the prevalent view is that a vibrant civil society (often defined in terms of high levels of membership and frequency of activism) is a prerequisite for democracy. For instance, late Ernest Gellner $(1994,189)$ had come to the conclusion that without civil society, the development of democracy is hardly possible. One assumption in the postSoviet Union era concerning Central and Eastern Europe has also been that in order for a democratic system of government to flourish in the countries in these regions, there is a need for the development of civil society that would limit the authority of the state (Diamond 1994, 8). The role the civil society has played in the transitions to democracy in several Eastern European countries has been viewed in the same light (Geremek 1992; Weigle and Butterfield 1992; Bernhard 1993; Smolar 1996; Uhlin 2009).

There is also a different category of literature that does not necessarily expect civil society to bring about a transition to democracy, but foresees civil society to make contributions to public policies and programmes. According to this literature, the civil society does not challenge the legitimacy of the political regime; it would rather have a relatively harmonious relationship with that regime, and it is thus able to contribute to the making of public policies and programmes.

The primary characteristics of this type of civil society are pluralism, toleration and civility; altruism, leading to the pursuit of the common good as the members of civil society themselves perceive it; emphasis on consensus; and the mutual

*Corresponding author. Email: heper@bilkent.edu.tr 
dependence of the state and civil society. ${ }^{1}$ In brief, the civil society in question connotes an organized associational life that is in search for a better society through public deliberation. $^{2}$

It is true that empirical reality in respect to the primary characteristics of civil society mentioned here would show variations from one context to another. Indeed, students of political theory and comparative politics have taken civil society as a venue of 'natural affections and sociability' as well as an arena where man 'regards other men as means'; it connotes 'rights' but also property, civility but also economic exploitation; and it invokes both the legally free individual and the community of free individuals (Seligman 1992, 3).

However, such objections to the present formulation of civil society are concerned with the question of to what extent the emergence of civil society we have in mind is probable. The students of civil society on which we draw upon in this essay have been, instead, preoccupied with the question of what type of civil society would best contribute to the flourishing of good society, by coming up with policies and programmes appropriate to that end.

This second conceptualization of civil society comes close to the model comprising ideal types formulated by Max Weber (1968). When one works with such a model, the empirical reality cannot be expected to exactly fit the ideal types in question (Martindale 1959, 69). Consequently, in such situations, one does not address oneself to the question of whether or not the empirical reality exactly fits a certain model; one only endeavours to show to what extent the former comes close to the latter (Freund 1968, 109).

This article adopts a model of civil society to study the contributions of civil society to public policy-making in consolidated democracies. This is because, if the consolidation of democracy is defined 'democracy becoming the only game in town', Turkey may be considered to have a consolidated democracy (Heper 1994; Özbudun and Yazıc1 2004; Kalaycıoğlu, Ergüder, and Çarkoğlu 2007). However, as democracy in Turkey has had its own ups and downs since the transition to democracy in 1945, almost all of the studies on civil society in this country have tended to focus on the role of civil society in respect to the (strong) state and democracy, rather than its contribution to public policy-making.

In this context, some students of civil society have noted that Turkey has had too strong a state and that this situation has left little scope for the emergence of an efficacious civil society (Alpay 1991; Tosun 2001). Most others addressed themselves to the questions of (1) how civil society has challenged various government policies concerning political, economic, and social issues; and (2) which alternative policies civil society itself would have formulated about these issues. ${ }^{3}$

As a consequence, these studies have not dealt with the question of under what type of conditions civil society and governments would have close working relations, and how in the process, civil society would be able to contribute to the public policymaking. ${ }^{4}$ The present study attempts to fill this vacuum. Thus, this article dwells upon the impediments and prerequisites vis-à-vis the flourishing of civil society as well as the consequent primary characteristics of civil society in consolidated democracies. All in all, the present article aims to identify (1) the circumstances and factors that impede and/or facilitate the development of civil society in question, (2) the resultant characteristics of that civil society in the case of Turkey, and (3) the consequent ability of the civil society in Turkey to effectively contribute to public policy-making in the country. 


\section{Impediments to and prerequisites for civil society}

\section{Impediments}

Widespread populism, clientelism, opportunism, and personalism (as against individualism) would constitute one set of impediments to the emergence and development of civil society. Virtually, sole emphasis on interest politics and rights-based individualism may encourage all kinds of egoistical acts. If government policies benefit almost solely one's own political supporters, it may create a situation where some groups in society may be less able than others to participate in civil societal activities (Hall 1995, 14).

Secondly, such developments as state-led modernization, industrialization, and/or economic development as well nation-building may work against civil society having autonomy from the state (Hall 1995, 12-13). In different degrees and manners, each of the above phenomena would lead to authoritarian systems of government (Hall 1995, 8). Consequently, little scope would be left for the development of autonomous voluntary organizations or associations. Moreover, under such circumstances, the designation of the common good by people, as they themselves see it, would also become impossible, because that task would in all probability be monopolized by the state itself.

Last but not least, such phenomena as ethnic nationalism, religious fundamentalism, and closed ideologies of different hues and colours would render the development of civil society almost impossible (Hall 1995, 16-17; Turner 2000, 31). ${ }^{5}$ In such cases, homogeneity and unanimity would be the ultimate goals, leaving little scope for pluralism. Exclusive identities and disrespect for the 'other', deriving from dogmatic tenets and rigid traditions as well as closed ideologies, would carry the day, all of which would discourage free dialogue and debate among and within the constituent spheres of civil society.

\section{Prerequisites}

One of the most important prerequisites for the flourishing of civil society is the presence of countervailing powers to the central authority (Hall 1995, 4). ${ }^{6}$ The inability of the centre to dominate the periphery opens the way for a polity where the name of the game is not suppression, but negotiation and persuasion. It is under such circumstances that societal elements would not be smothered by the state (Foley and Edwards 1996, 44).

Historically, major institutions that limited the powers of the state turned out to be aristocracy ${ }^{7}$ and/or middle class. In the case of the latter, there was a need for that class to comprise entrepreneurs rather than bureaucratic and/or other elite elements, for bureaucratic stratum and/or intelligentsia would not necessarily cherish liberal practices; thus, they would not in all probability have a sympathetic attitude towards voluntary associations. Furthermore, entrepreneurial middle classes would in general be the supporters of the rule of law, for they need an environment where the members of these classes are protected against all kinds of encroachments towards their rights and where contracts they enter into would be under the protection of the state. In any case, the rule of law is indispensable for freedom of expression, which in turn facilitates dialogue within and among the constituent units of civil society.

The second significant prerequisite for the development of civil society is the existence of a market economy. ${ }^{8}$ Where there is a market economy, the bulk of the 
resources that a country commands is not controlled by the state. The non-monopolization of these resources by the state in turn makes the autonomy from the state of business firms as well as other societal institutions possible. Moreover, market economy, which is more productive than alternative models of economic system, enables the members of civil society to have at their disposal more resources that they can use for civil societal activities (Shils 1997b, 331).

The spread of literacy and mass print culture constitutes the third vital prerequisite for civil society. Civil society is a debating society writ large. Both among and within its constituent spheres, there should be a continuous and lively discussion of the social, economic, and political issues. For that debate to be meaningful, the parties involved should be well informed concerning the three sets of issues in question (Hall 1995, passim).

For debate among the constituent spheres of civil society to take place, there should be horizontal linkages among those spheres, the fourth significant prerequisite for the development of civil society. If historically a society evinced a segregative structure, there would be a need to desegregate that structure so that the development of reciprocal and cooperative relations among constituent spheres of civil society would flourish (Eberly 2000, 17). ${ }^{9}$

One should also not come across an in-group-out-group orientation among the members of civil society, the fifth prerequisite. Such an orientation is usually an upshot of lack of trust among people. Trust among people is yet another important prerequisite for civil society, for in its absence, widespread dialogue and exchange of ideas would not be possible (Newton 2001, 202).

\section{Primary characteristics of civil society}

Where, on the whole, the impediments mentioned above have been absent and the prerequisites delineated above have been present, it would be possible for a civil society to flourish. One of the characteristics of that civil society would be pluralism. Pluralism in question turns out to be two-fold. Firstly, such distinct spheres as politics, economy, and religion would have autonomy from the others. Secondly, internally each of those spheres would function in a plural manner. In both cases, there would not be hegemonic domination on the part of any of those spheres, for civil society is a venue of conflict as well as consensus (Shils 1997b, 330). It follows that civil society is a venue where several societal and political actors meet, interact, and discuss in order to arrive at a view all of them can live with.

Pluralism by its very nature leads to disagreement. In civil society, disagreement is looked upon as inevitable, for dialogue rather than the imposition of certain views upon others is the name of the game. In civil society, disagreement turns out to be nonhostile; the parties to the dialogue endeavour to reach a common point rather than try to refute each and every point made by the others. By common point, the reference is not to unanimity but, as pointed out, to consensus. Thus, dialogue would become productive and civil society would manage to come up with its own constructive and feasible policies and programmes. This would render civil society an efficacious actor vis-à-vis the state.

It should also be noted that in two senses, the consensus in question would be a dynamic one. Firstly, for a particular time period, there may be diverse conceptions of the common good, and in good faith, the members of civil society would strive to arrive at a consensus on what is perceived as the common good. Secondly, the 
members of civil society would adopt a future orientation in respect to the common good, keeping in mind that what is presently considered as the common good may not be in the best interest of the future generations (Walzer 1992, 98; Shils 1997b, 346).

Altruism is yet another important characteristic of the members of civil society. Altruism is one of the factors that lead the members of civil society to have a concern for the common good. The latter would facilitate arriving at a consensus. ${ }^{10}$ In the process, members of civil society look after the interests of the others too and thus promote solidarity with other societal groups. To use Edward Shils's terminology, while conflict is the 'spice of life', solidarity is 'the cradle of altruism' (Shils 1997a, 97).

Here, it should also be noted that the common good in question is not taken as a moral idea of social order dictated by such impediments to civil society as ethnic nationalism, religious fundamentalism, and/or closed ideologies of different types. Rather, it should be envisaged as an ethical idea of social order. The former is timeand place-specific and less open to different interpretations, while the latter is formulated in more general terms that can be more easily accommodated to different milieus and needs. It would thus be easier for the members of civil society to reach consensus (Eberly 2000, 13).

The members of civil society act in the manner delineated here because they adopt a responsive and, certainly, a sympathetic attitude towards others' particular views, preferences, and interests. After all, the members of civil society need to take into account others' views, preferences, and interests when formulating the common good. It follows that the common good discussed here would be arrived at as a consequence of efforts to reconcile the particular and the general. It should also be underlined here that the particular and the general can be reconciled only by those who do not focus exclusively either on the particular or on the general. Thus, neither the (strong) state, as defined by Evans, Rueschemeyer, and Skocpol (1985), nor interest groups, such as trade unions, businessmen's associations, and the like, can be considered as civil societal organizations. It follows that pressure groups rather than interest groups can be construed as civil societal organizations.

Since deliberations in civil society are conducted in a collective manner, another characteristic of civil society is toleration. Toleration involves considering the 'other' at least equal in dignity, intelligence, and trustworthiness, and thus having respect for the other (Shils 1997b, 338). Collective decision-making is not possible unless egalitarianism as a principle governs the relations among the parties involved in deliberation.

In collective decision-making, egalitarianism is complemented by civility, which involves displaying courtesy and skill of conducting a debate without acting in an offensive manner to others. Toleration makes possible joint endeavours; civility helps to maintain a smooth dialogue among parties. Civility also contributes to a process vital to civil society - participants to a debate not only being interested in refuting others' arguments, but also in viewing such an occasion as an opportunity to learn from others' views. They thus become capable of jointly formulating policies and programmes that no group strongly opposes (Shils 1997b, 320-55).

As for the civil society-state relationship, this particular relationship is more complex than often realized. According to the received wisdom, civil society topples authoritarian political regimes from power. Once a more democratic system of government is set up, civil society tries to prevent that system of government from drifting to authoritarianism, and from time to time, it doubles as the state when the 
state is unable to attend to some matters deemed important (Tusalem 2007). Civil society acts in this manner where democracy has not been consolidated.

In the perspective developed here, civil society is expected to conduct itself in other ways. In a consolidated democracy, civil society is essentially a 'space of uncoerced human association' (Cohen and Arato 1992, 30; Walzer 1992, 89). Civil society primarily acts in an advisory capacity to the state, by coming up with policy and programme proposals on diverse matters, all with a view to bringing about a 'better quality of life'.

Turning to the state, for one thing, the state maintains the rule of law and, thus, not only safeguards civil society against the state functionaries that may be involved in illegal action against what they consider as 'undesirable' elements of civil society, but also prevents some non-state groups from acting in a similar manner towards the members of civil society (Shils 1997b, 332). It follows that the state plays a protective role in respect to civil society, for it regulates all associational activities by fixing their boundaries (Walzer 1992, 103). For this reason, neither the state nor civil society would act as rivals vis-à-vis each other; consequently, they do not harbour hostile attitudes towards one another. On the contrary, concerning a number of issues, they complement each other.

\section{Civil society in Turkey}

\section{Impediments to civil society}

May one consider populism, clientelism, opportunism, and personalism as obstacles to the development and flourishing of civil society in Turkey? Historically, in the absence of intermediary structures, particularly in the Ottoman Empire (circa 12991918), but also in the Republican period (1923 to the present), there has been a direct relationship between the subjects (in the Ottoman Empire) and the citizens (in the Republic), on the one hand, and the state, on the other (Mardin 1973; Heper 1980). The Ottoman sultans considered themselves responsible for the welfare of the people, and the people, when in need of resources and other amenities, had nowhere to turn to but the state. In the Republican period, too, one has observed a similar situation, particularly following the transition to the multi-party period (1945) (Heper 1985, ch. 5). Consequently, if civil society is expected to pay attention to the common good and if people have to display a certain level of altruism, Turkey has not been the most suitable context for such phenomena to hold sway. For in Turkey, rather than forming horizontal relations with others and trying to oblige the state to act in a responsive manner to their group interests, peripheral groups have had vertical relations with the state, expecting the latter to be responsive to their specific interests. ${ }^{11}$

Throughout the Republican period, there have been intense efforts for modernizing the country, starting with the process of industrialization and continuing with economic development in general. At the same time, there have been a gradual and constant progress towards a more open polity and society. The basic reason behind this particular evolution has been the fact that modernization was identified with Westernization, and democracy was viewed as an indispensable component of Westernization (Heper 1992, 146). The modernization project in question aimed at bringing about a transition from a religious community, considered to have been under the influence of the superstitions and dogmas derived from Islam, to a secular nation, the members of which were expected to use their own reasoning faculties and not turn to the Book whenever they were going to make an important decision. The founders of 
the Republic concluded that the new generation of Turks would comprise people who would 'think logically' (Karpat 1959, 54).

Consequently, as early as 1924 and 1930, Turkey experienced two, though brief, periods of multi-party politics. They were brief, because they were considered to have formed a threat to the modernization project in question, not because of an inherent opposition to a more open polity (Heper 1985, ch. 3). Consequently, as the modernization project made progress, democratization gained speed. Thus, Turkey made a transition to multi-party politics in the mid-1940s. The military interventions that took place in the later decades did not aim at long-term authoritarian regimes; the juntas involved were always of the opinion that they were saving democracy from itself and that they were not acting out of the corporate interests of the military or of their own.. That must be why while several Latin American countries experienced long-term military authoritarianisms, in Turkey, when it intervened, the military always gave a date for its return to the barracks and kept its promise. Furthermore, from the late 1990s onwards, another direct military intervention in which the military took power into its own hands became most unlikely. When the military ousted a coalition government from power, as in 1997 (the coalition government of the religiously oriented Welfare Party and the secularly oriented True Path Party), it acted in concert with several institutions, i.e., universities, courts of law, some political parties, and societal groups. In addition, the behind-the-scenes interventions of the military in day-to-day politics have also become somewhat less frequent, though they did not come to a definitive end. On the other hand, as would be expected, in the wake of the military interventions, there lingered an animosity on the part of those removed from their privileged positions towards those in the military, polity, and society who were presumed to be the beneficiaries of these interventions.

In this regard, Turkey's efforts to become a full member of the European Union (EU) and consequently its obligation to conform to the acquis communitaire of the EU also played a significant role. Among other things, the military was deprived of its executive power over individual ministries. It could no longer be engaged in the follow-up activities regarding the recommendations that the National Security Council (NSC) made to political governments. ${ }^{12}$ Also, the governments were no longer obliged to give priority consideration to the recommendations of the NSC (Özbudun and Yazic1 2004, 31-47).

The EU has also contributed to civil society's beginning to play a more significant role in Turkey. By its 1999 Helsinki and 2002 Copenhagen decisions, the EU facilitated Turkey's reforms concerning the freedom of association in the country (Grigoriadis 2009,58 ). It has also provided credibility and legitimacy to the demands of civil societal actors in Turkey. In addition to this outside pressure, civil societal actors, now gradually empowered by their 'external ally', also came up with demands which the governments were obliged to meet. For instance, the Law on Associations was revised in a liberal direction. (Tocci 2005, 81). Gradually, state elites as well as political and economic actors have begun to recognize the increasing importance of civil society for Turkey's further political and economic development (Keyman and Öniş 2007, 283-4).

The overall development delineated here increasingly left more scope for action to the civil society in Turkey. At the turn of the century, the Turks began to enjoy additional liberties and rights. Yet, whether presently (May 2010) the intellectually freed individuals have generally become willing and enthusiastic to take initiative on many, particularly sensitive, issues, remains a moot point. 
Have such phenomena as ethnic nationalism, religious fundamentalism, and/or closed ideologies of different types rendered the development of civil society in Turkey impossible? The ethnic separatism first came to the agenda of the republican Turkey in the early 1920s and lingered on until the end of the 1930s. However, at the time, it did not, on the whole, lead to a serious cleavage in the society or, for that matter, in the polity. In fact, it has been suggested that except a few individuals, the bulk of the political stratum has not viewed the Kurdish rebellions as an ethnic issue (Heper 2007). In the 1984-1999 period and later, when Turkey experienced similar 'troubles', the situation had been somewhat different. Although for the bulk of the people, it continued to be a non-issue - and consequently this issue has not divided large numbers of people into opposite camps evincing generalized hostility towards each other - from time to time, some students of the Kurdish affairs argued that Turkey faced a rising ethnic nationalism on the part of both the Kurds and the Turks.

The so-called 'religious fundamentalism' has posed a greater and longer-lasting threat to constructive debate in Turkey. From 1970, the date the first religiously oriented political party was set up, to the present, this issue divided the Turks into two almost warring camps. It thus turned out to be one of the important reasons behind the indirect military intervention of 1997 . Some concluded that religiously oriented political parties have had used religion for political purposes.

The issue in question became particularly acute following the 2002 and 2007 general elections, when a religiously oriented political party, the Justice and Development Party (Adalet ve Kalkınma Partisi [AKP]), won these elections and ruled the country as a majority party. This situation made some secularists concerned about the ultimate aims of the AKP - whether or not the party would try to bring back a state based on Islam. While the AKP's leadership cadres, led by Prime Minister Recep Tayyip Erdoğan, have argued that they are pious people and prefer secular politics, the secularist groups have thought that the AKP has been engaged in takiyye (dissimulation), hiding their ulterior motives until the time is ripe to disclose them. This conflict has made it impossible for the two groups and their followers to be engaged even in a semblance of constructive debate.

\section{Prerequisites for civil society}

The first prerequisite for the flourishing of civil society is the presence of countervailing powers to central authority. In Ottoman times, the bureaucratic centre managed to exercise control over all sources of power in the realm (Mardin 1969, 259). Under the circumstances, there was little scope for the development of any kind of social stratum with autonomy from the state. Furthermore, the social strata that existed were based neither on property rights, nor were they, in the Durkeimian sense, 'secondary structures' that could act as countervailing powers vis-à-vis the state. The closest Ottoman equivalents to intermediary structures were trade guilds, village councils, and tribal organizations. The latter could not really be considered as intermediary structures, because they could exercise no control over the activities of the state (Heper 1985, 101; 1991a, 13). In any case, these entities enjoyed only limited autonomy, for their activities were closely monitored by the bureaucrats appointed by the state (Mardin 1969, 265; 1988, 23-6).

Until the last two decades of the twentieth century, the situation in the Turkish republic had not been any different. It is true that over the years, there had been a proliferation of unions, voluntary organizations, associations, and nongovernmental 
organizations. However, even what had been considered as prominent interest group associations in Turkey, such as the Industrialists and Businessmen Association of Turkey (Türkiye Sanayiciler ve İşadamları Derneği [TÜSİAD]), have had little or no impact on the making of public policies and programmes. ${ }^{13}$

Turning to the second prerequisite for the development and flourishing of civil society, i.e., market economy, in the Ottoman Empire, the state dominated not only society but also economy. The Sultan himself was responsible for the welfare of his subjects. The major concern of Istanbul, the capital city of the Empire, was of providing primarily for the welfare of the ruling stratum, for instance, by transferring to the city adequate foodstuffs, rather than promoting economic development of the country in general (Mardin 1969, 260).

This situation was coupled with an ethnic division of labour: the Muslims preoccupied themselves with agriculture and the non-Muslims with finance and trade. This state of affairs further weakened the hand of the social groups vis-à-vis the state. One upshot of this particular arrangement was that from the early nineteenth-century onwards, what could pass as interest group associations were, in fact, entities set up by the state and used by it as its own instruments (Heper 1991a, 15).

By the closing decades of the Empire, the bulk of the non-Muslim economic actors had chosen an exit strategy and had set up their own states. Thus, when the Republican Turkey was founded (1923), the country had neither adequate manpower nor capital for the flourishing of a market economy. Still, between 1923 and 1929, the country experimented with a liberal economic policy. However, as that policy turned out to be a failure and, what is more, the country also strongly felt the adverse effects of the 1929 world economic crisis, Turkey adopted in 1930 a state-led economic policy. This policy continued even after 1950, when the centre-right governments came to power. Among other things, the number of the state economic enterprises kept going up. In the process, industrialists and businessmen needed the state as a provider of credit for the start of new economic ventures. Under such circumstances, the private sector could hardly challenge the state.

It is true that with the coming to power of the Motherland Party in 1983, Turkey substituted an export-led economic policy for an import-led one. However, the architect of this policy, Turgut Özal, Prime Minister from 1983 to 1989, had as his targets the rendering of the Turkish economy competitive at international markets and the sidelining of the traditional civil bureaucracy, which he perceived as an obstacle to the economic policy adopted. Özal did not look with sympathy to the contribution of the private sector to the devising of economic policies (Heper 1991b, 173-6). This was apparent from the fact that Özal set up a brand new economy public bureaucracy (Heper and Sancar 1998, 150-4).

It cannot be denied that at the turn of the century, Turkey had come to have a dynamic private sector that successfully competed at international markets and commanded a significant amount of capital. In the process, in some conservative Anatolian cities, if not in the more progressive major urban centres as Ankara, Istanbul, and Izmir, a new self-financing middle class emerged and, as a consequence, there has been a talk of the 'thickening of civil society' (Yavuz 2009, 141, 146). Furthermore, the relationship between these economic groups and the state has increasingly become one of dialogue. Yet, that dialogue has not been a continuous one, and in most instances, the last word still belonged to the state.

As to the widespread literacy, a shared means of communication, and a mass print culture, here Turkey has fared fairly well. In 2004, the literacy rate was $95.5 \%$. That 
same year, $95 \%$ of homes had a TV set, and the average time period people watched TV was four and a half hours per day. Also, everyday people spent, on the average, three hours to listen to radio. The latter constituted $73 \%$ of the population; those in the 15-24 years age groups constituting the majority of this population. From the early 1990s onwards, the satellite system and cable TV too became quite widespread, especially in the urban areas. As to the Internet, at the end of 2006, there were approximately 28,000 cable internet and 3,700,000 ADSL customers. Turning to the print media, in 2007, Turkey had 5844 periodicals (magazines, newspapers, and other periodicals) (Heper and Criss 2009, 58-9, 202).

Given these figures, the people in Turkey must have been quite well informed on the major issues facing the country. One may assume that particularly in the Republican period, one cannot talk of the segregation of people into isolated communities that would have barred horizontal linkages among the constituent spheres of civil society. However, whether the presumed well-informed people interacting with each other have also been engaged in a constructive debate leading to a consensus and, thus, policy recommendations, is another question. We return to that issue below.

\section{Primary characteristics of civil society}

Does one come across pluralism in Turkey, i.e., do any of the different spheres such as politics, economy, and religion not dominate others, and does each and every such sphere internally function in a plural manner? Since 1945, there has been multi-party politics in Turkey. From 1961 onwards, with the adoption of the system of proportional representation in national elections, Turkey experienced a political party inflation. The number of political parties represented in Parliament was reduced to manageable levels only when Turkey adopted in 1983 a rather high electoral quotient of $10 \%$. On the other hand, the plurality in the number of parties has not been matched by pluralism in the internal functioning of those parties; Turkish political parties have always been dominated by their leaders. ${ }^{14}$

Furthermore, as noted above, in Turkey, the social groups could hardly impinge upon the state. One expected consequence of this situation has been the virtual absence of responsiveness on the part of governments to these groups. For instance, the economic actors have found it difficult to impinge upon the state actors. In fact, governments often placed their supporters in the governing bodies of employers' peak interest group associations, such as the Union of Chambers and Stock Exchanges of Turkey (Türkiye Odalar ve Borsalar Birliği [TOBB]).

From the 1980s onwards, when Turkey adopted an export-oriented economic policy instead of an inward-looking one, the situation remained not much different from the earlier periods. It is true that the governments allowed interest group associations to freely articulate their views and interests; however, whether the governments have incorporated those views into their policies remained an open question. In any case, when needed, it was the governments that initiated meetings with the representatives of the associations in question, and not the other way round. In any case, such meetings were held infrequently. Consequently, the associations in question complained that the governments did not include them in the public policy-making. Although Turkey adopted a market economy and despite the fact that the private sector began to command rather ample resources from the 1980s onwards, the interest group associations in the country nevertheless remained as 'outsiders' vis-à-vis the public policy-making (Heper 1991a, 18). 
Turning to the sphere of religion, in the Ottoman Empire, in general, Islam did not turn out to be proscriptive concerning state policies; rather, resort was made to this religion in order to legitimize the policies already made. On the whole, the Muslim subjects were granted leeway to live their religion in the manner they chose to. It is true that people turned to religious personages for guidance concerning several issues in their personal and, to some extent, community lives; yet, the type of Islam, which was salient, was in general the Sufi version of Islam (Cumhur 1997, 40-2; İnalcik 1997). This version of Islam urges individuals to preoccupy themselves with upgrading themselves morally and, thus, treating others with tolerance and respect (Sedgwick 2000, passim).

The Sufi version of Islam in the republican Turkey had its origins in the frontier religion of the Ottomans. The frontier Islam was a mystic, not a doctrinaire, form of Islam. The Islam in question was influenced to a great extent by Ahmet Yesevi (10931166), a twelfth-century mystic who brought Sufism from Central Asia to Anatolia in the thirteenth century. The Yesevism was open to all, whether destitute, traveller, orphan, Muslim, or non-Muslim. Yesevi's teaching also included a call for altruism. Some other great humanists of the same era - Yunus Emre (1238?-1320) and Mevlana Celaleddin-i Rumi (1207-1273) - also left their imprint in the hearts and faith of the people. Thus, the mystic Islam began to spread in Anatolia in the thirteenth and fourteenth centuries (Karpat 1973, 24-5; Cumhur 1997, 40-2). In the process, tolerance in the Ottoman Empire implied an acceptance of difference (Rodrique 1995, 85-6; Karpat 2001, 197-8).

In the Republican period, since the 1970s, the Islamist Fethullah Gülen (1941present) movement has become quite popular. Its followers are of the opinion that that the movement has inherited the Sufi heritage of Anatolia (Introvigne 2006, 42). This idea has gained credence from Gülen's reference to what Yunus Emre once said: 'If you look for God, look for him in your heart. For He is not in Jerusalem, Mecca, or the Pilgrimage'.

Gülen movement has had a mixed record in respect to civil society in Turkey. On the one hand, the movement has placed emphasis on social harmony, tolerance, and respect for others; on the other hand, by placing emphasis on community rather than individual, it has not always promoted the formation of a sense of individualism (Yavuz 2003, 203; Sevindi 2008, 37, 68).

Here, it should also be noted that the Gülen movement has been suspected of being a supporter of political Islam. There is, in fact, a sharp disagreement in Turkey on whether or not secularism in the country faces a serious threat. The findings from reliable nationwide surveys, however, indicate that people in Turkey have a rather balanced approach towards the role religion should play in politics and society. For instance, a 2006 nationwide survey found that while $84.2 \%$ of the people vote for political parties that, they think, have internalized secular republican values, $78.2 \%$ wish to see that the same political parties respect their Islamic values and sentiments and pursue policies along those lines. People in Turkey have also a quite tolerant attitude towards how others practise their religion. The survey in question has found that a person who believes in Allah (the Muslims' God) and His prophet, Muhammad, is considered a Muslim by $79.9 \%$ of respondents, even if that person does not do his or her prayers (Heper 2009, 416-17). It is patent that as far as the populace in general is concerned, religion would not act as an obstacle to trust and cooperation among the people.

After all, in the Republican period, all along, an effort has been made to emancipate citizens from the presumed chains engendered by Islam. The goal was to enable 
the people to make their own decisions rather than making resort to the teachings of Islam. It was for this reason that the Directorate of Religious Affairs (affiliated to the Prime Ministry) was given the responsibility of seeing to it that the preachers at mosques delivered sermons along the lines discussed above. ${ }^{15}$ Islam was also expected to provide solidarism among the Muslims and serve as an antidote against the radical ideologies on the right and on the left as well as against ethnic separatism. ${ }^{16}$

In this context, one sore point throughout the Republic has been the conscious ignoring of the presence of the country's Alevis, the Turkish version of Shiites, ${ }^{17}$ and thus remaining unresponsive to their needs. Obviously, this particular policy somewhat detracted from pluralism one comes across in such matters in Turkey. This situation may change in the near future; at the turn of the century, on different occasions, the Directorate declared that some reforms will be made regarding this issue, though, up until the present writing, no substantive steps had been taken in this regard.

Does one come across in Turkey friendly disagreement that makes dialogue and thus reaching consensus possible? One important factor that stands in the way of dialogue ending up in consensus in Turkey has been the phenomenon of lingering disagreement in high politics on such questions as political Islam, ethnic separatism, and even the procedural rules democracy itself, which in turn has led to similar cleavages among the societal actors. It is true that Turkey has had myriad societal organizations and associations, but the latter have been divided among themselves on cultural and/or ideological issues in question. The tension between the secular TÜSİAD and the religiously oriented MÜSİAD (Müstakil Sanayici ve İş adamları Derneği [Association of Independent Industrialists and Businessmen]) is a case in point (Şimşek 2004, 61-2). This polarization, which involved an insistence by both parties on 'absolute truths', prevented them from acting in a sensible manner and meeting at a common ground (Kasaba 1997, 18). To give one important example, neither secular Kemalists nor Islamists, particularly the former, have shown an inclination to agree on the common good (Şimşek 2004, 63). The 'secularist'-'Islamist' confrontation was intertwined with the absence of interpersonal trust, respect for the other, and thus 'associability'. This state of affairs at times also displayed an absence of civility on the part of the members on both sides (Kalaycioğlu 2002, 62-6).

Concerning the state-civil society relations in Turkey, the state in the country has continued to have its autonomy from society. It is true that the state came up with a legal order 'based on criteria, which are universally applicable' (Toprak 1995, 88), but the same state has not been able to systematically enforce the laws and regulations (Kalaycioğlu 2002, 70). As for the society, the latter has always been obliged to remain in an 'outsider' position vis-à-vis the state.

\section{Conclusion}

In Turkey, such lingering impediments as populism, clientelism, and opportunism seem to have prevented the members of civil society from entertaining an idea of a common good, and this has become an obstacle for the development of a dynamic consensus when needed. This state of affairs must also have had an adverse impact on the development of trust among the members of civil society and, consequently, on the building of horizontal linkages among the members of civil society. Similarly, the continuing weakness of civil society has prevented it from acting as an efficacious countervailing power vis-à-vis the state. This is because the state has remained too strong for the flourishing of an egalitarian relationship between it and civil society. 
On the other hand, there have been in Turkey a certain degree of modernization, economic development and industrialization, the spread of literacy, and mass print culture as well as the consolidation of democracy. It is true that in the post-2002 Turkish political life, there have been a debate on whether or not the 'religiously oriented' government party (the Justice and Development Party) has subscribed to political Islam. Yet, there has been an absence of a generalized hostility among various elements in society as a consequence of the fact that one has not come across in Turkey ethnic nationalism, widespread religious fundamentalism, and closed ideologies with an impact on society for long periods of time. This must be the reason why in Turkey there have emerged numerous civil societal entities, and some of them some of the time have managed to make a difference, despite the great odds we have mentioned. For example, the Environmental Problems Foundation of Turkey played an important role in the government's reversal of its decision to construct a thermal power plant in the town of Gökova in south-western Turkey. Similarly, The Purple Roof Women Centre Foundation along with the Women Entrepreneurs Association of Turkey (Türkiye Kadın Girişimciler Derneği [KAGİDER]) and the Association of Supporting and Training of Women Candidates (to Parliament) (Kadın Adayları Destekleme ve Eğitme Derneği [KADER]) set up a platform and played an important role, among other things, in the amendment of the 1982 Constitution for promoting egalitarianism among men and women, and husband and wife in Turkey, and lifting Turkey's reservations to the United Nations' Convention on the Elimination of All Forms of Discrimination against Women (1979).

On the other hand, it is true that in some such instances, one has come across civil societal entities with high levels of membership and frequency of activism. Yet, for the most part, such entities had little or no impact on public policies and programmes for the reasons delineated above.

What might be some of the implications of the findings from the Turkish case for the general literature on civil society? The pre-transition-to-democracy civil society and the post-transition-to-democracy civil society mentioned in the 'introduction' resemble the two models of civil society drawn up by Foley and Edwards. They have made a distinction between the so-called 'Civil Society I' and 'Civil Society II' models. The former model of civil society comprises associational life that is characterized by civility on the part of its members, while according to the latter model, the civil society is a sphere of action that has its autonomy from the state and, thus, is able to resist an authoritarian regime (Foley and Edwards 1996).

One extreme example of 'Civil Society II' in question has been provided by Kopecký and Mudde (2003, 4), who attributed to 'uncivil movements' in Eastern Europe such civil society functions as acting like advocacy networks. On the other hand, the model of civil society we have adopted in this article is an elaboration of 'Civil Society I' discussed above.

Here, it may be suggested that a transition from 'Civil Society II' to 'Civil Society I' would be difficult, for in 'Civil Society II', there would develop hostility on the part of civil society towards the state, and the resultant tension between civil society and the state may be expected to linger on for long periods of time (Tusalem 2007, 364). In contrast, in 'Civil Society I', civil society and the state would be expected to have harmonious relations between them.

However, if civil society had hardly played a role in the transition to democracy, the outcome may be expected to be different. In some such cases as the Turkish one, there was no need for civil society to take part in the democratizations of the political 
regime, and not having a prejudice towards the state, the emerging civil society came to display at least some characteristics of 'Civil Society I'.

Turning to the model of civil society developed and employed in this article, it should be kept in mind that one cannot definitively argue that there is or there is not a civil society in a given country. Depending upon the existence and non-existence of the constellations of impediments and prerequisites, one may come across certain dimensions of civil society, and not other dimensions, in a particular time and place. Which constellations of impediments and prerequisites would lead to which kind of civil society in specific contexts should be the subject matter of future empirical studies. Needless to point out, such endeavours should be made from a comparative perspective.

\section{Notes}

1. We elaborate each of these characteristics of civil society in the following sections.

2. For this definition, the authors draw on Keyman and Öniş (2007), who in turn have been inspired by Ehrenberg (1999) and Kaldor (2003).

3. For examples of studying civil society in Turkey from the perspective of the problems of democracy (and/or citizenship) rather than those of civil society, see Göle (1994), Özbudun (1997), Sarıbay (1997), and Kadığlu (2002).

4. There is one single study of civil society in Turkey, the theoretical perspective of which comes close to the perspective suggested in the present article (Şimşek 2004). Although that study looks at somewhat different versions of two prerequisites (existence of a market economy and horizontal linkages among different spheres of civil society) and different versions of some characteristics of civil society (existence of friendly disagreement, civility, and the importance of the rule of law in state-civil society relationship) taken up in this article, it too takes up the role of civil society in respect to the role it plays concerning the development of democracy.

5. We assume that ethnic nationalism, religious fundamentalism, and closed ideologies would constitute impediments for the flourishing of a vibrant society, because on the whole, those who subscribe to such thought patterns do not choose to interact with others in a respectful manner and, in fact, attempt to impose their preferences on others. It is, of course, possible that those who have adopted such world views may use peaceful means of persuading their detractors, though such cases would be expected to constitute the exception rather than the rule. In any case, the dominant discourse of a civil society in consolidated democracies should be informed by democratic norms. On this issue, see the country studies in Alagappa (2004).

6. Hall (1995) provides historical examples of nobility and churches, both acting as countervailing powers to kings.

7. For the importance of aristocracy as a countervailing power, see Bendix (1978, ch. 7).

8. On the relationship between market economy and democracy, see Dahl (1998, ch. 13).

9. It should also be pointed out that in the absence of such horizontal linkages, the vertical relations between the state, on the one hand, and individuals or the constellations of individuals, whether formally organized or not, on the other, leave societal actors vulnerable to undue control from above.

10. That the civil society is concerned with public rather than private interests is underlined, among others, by Diamond $(1994,6)$.

11. See, inter alia, Kalaycı̆ı̆lu $(2001,64)$.

12. The NSC comprises the president of the Republic, key cabinet members, and the members of the high command.

13. It is for this reason that, on the whole, the individual holding companies only try to exercise influence upon bureaucrats responsible for the implementation of policies so as to make it beneficial for them (Heper 1991a, 17). We make reference to TÜSİAD in this context, because as already implied above, among all the interest group as well as civil society associations, TÜSİAD is considered as the organization with maximum influence over the Turkish government. We do not consider interest groups as civil society groups, because in our conceptualization of civil society, civil society groups are not supposed to act as the 
spokespersons of a particular interest; rather, they are expected to promote the common good as they see it and do this while maintaining a harmonious relationship with the state. Consequently, for us, in addition to the ones we have already alluded to, some other examples of civil society organizations in Turkey are the Association of the Environmental Protection and Greening of Turkey (Türkiye Çevre Koruma ve Yeşillendirme Kurumu [TÜRÇEK]), the Association of the Protection of Environment and Cultural Values of Turkey (Çevre ve Kültür Değerlerini Koruma ve Tanıtma Vakfi [ÇEKÜL]), the Foundation for Combatting Soil Erosion, Reforestation, and the Protection of Natural Habitat of Turkey (Türkiye Erozyonla Mücadele, Ağaçlandırma ve Doğal Varlıkları Koruma Vakfı [TEMA]), the Greenpeace of Turkey (Greenpeace Türk), the Purple Roof Women Centre Foundation ('Mor Çatı' - Kadına Şiddetle Mücadele Vakfi), and the Water Foundation (Su Vakfi).

14. It must be noted in passing that in Turkey, the absence of intra-party democracy has been a mixed blessing; in parties such as the Nationalist Action Party and the Justice and Development Party, the leaders prevented the parties from drifting to anti-system tendencies. This has contributed to the flourishing of civil society.

15. For an elaboration, see Shankland (1999, 28-31).

16. The disagreement among the elites on this issue is a different story, which we take up below. 17. In fact, Alevis do not use the appellation 'S $S i$ ' $i$ ' for themselves (Shankland 1999, 139).

\section{Notes on contributors}

Metin Heper is a Professor of Politics and Provost at Bilkent University and a founding and honorary member of the Turkish Academy of Sciences. He had been Martin Lester Fellow at Hebrew University of Jerusalem, Simon Senior Research Fellow at Manchester University, Research Fellow at Harvard University, Fulbright Scholar and Visiting Professor at Connecticut University, Madeleine Haas Russell Visiting Professor at Brandeis University, and Fulbright Scholar and Visiting Professor at Princeton University. Professor Heper does research on democracy, secularism, religion and politics, military and politics, and ethnicity and politics in Turkey. He is author of The Historical Dictionary of Turkey (Scarecrow, USA), The State Tradition in Turkey (Eothen, UK), İsmet İnönü: The Making of a Turkish Statesman (Brill, the Netherlands), The State and Kurds in Turkey: The Question of Assimilation (Palgrave Macmillan, UK).

Senem Yıldırım is a Ph.D. candidate at the Department of Political Science, Bilkent University. She does research on contemporary political theory and civil society.

\section{References}

Alagappa, M., ed. 2004. Civil society and political change in Asia: Expanding and contracting democratic space. Stanford, CA: Stanford University Press.

Alpay, Ş. 1991. Türkiye'de devlet-sivil toplum dengesi yeniden kurulmalı [Inequality between the state and civil society in Turkey should be removed]. In Sivil toplum, ed. Yurdakul Fincanc1, 17-26. Istanbul: Türkiye Sosyal Ekonomik Siyasal Araştırmalar Vakfi.

Bendix, R. 1978. Kings or people: Power and the mandate to rule. Berkeley: University of California Press.

Bernhard, M. 1993. Civil society and democratic transition in East Central Europe. Political Science Quarterly 108, no. 2: 307-26.

Cohen, J.L., and A. Arato. 1992. Civil society and political theory. Cambridge, MA: MIT Press.

Cumhur, M. 1997. Anadolu'nun bütünleşmesinde Ahmed Yesevi'nin yeri [Ahmed Yesevi's role in the cultural integration of Anatolia]. Ankara: Ankara Kültür Merkezi.

Dahl, R. 1998. On democracy. New Haven, CT: Yale University Press.

Diamond, L. 1994. Rethinking civil society: Towards democratic consolidation. Journal of Democracy 5, no. 3: 4-17.

Eberly, D.E. 2000. The meaning, origin, and applications of civil society. In The essential civil society reader: The classic essays, ed. D.E. Eberly, 3-29. Lanham, MD: Rowman \& Littlefield. 
Ehrenberg, J. 1999. Civil society: The critical history of an idea. New York: New York University Press.

Evans, P.B., D. Rueschemeyer, and T. Skocpol, eds. 1985. Bringing the state back in. Cambridge: Cambridge University Press.

Foley, M.W., and B. Edwards. 1996. The paradox of civil society. Journal of Democracy 7, no. 3: $38-52$.

Freund, J. 1968. The sociology of Max Weber. Trans. M. Ilford. New York: Pantheon.

Gellner, E. 1994. Condition of liberty: Civil society and its rivals. London: Allen Lane.

Geremek, B. 1992. Problems of postcommunism: Civil society then and now. Journal of Democracy 3, no. 2: 3-12.

Göle, N. 1994. Towards an autonomization of politics and civil society in Turkey. In Politics in the third Turkish Republic, ed. M. Heper and A. Evin, 213-22. Boulder, CO: Westview Press.

Grigoriadis, I.N. 2009. Trails of Europeanization: Turkish political culture and the European Union. New York: Palgrave Macmillan.

Hall, J.A. 1995. In search of civil society. In Civil society: Theory, history, comparison, ed. J.A. Hall, 1-31. Cambridge: Polity Press.

Heper, M. 1980. Center and periphery in the Ottoman Empire with special reference to the nineteenth century. International Political Science Review 1, no. 1:81-105.

Heper, M. 1985. The state tradition in Turkey. Walkington: Eothen Press.

Heper, M. 1991a. The state and interest groups with special reference to Turkey. In Strong state and economic interest groups: The post-1980 Turkish experience, ed. M. Heper, 3-23. Berlin: Walter de Gruyter.

Heper, M. 1991b. Interest group politics in post-1980 Turkey: Lingering monism. In Strong state and economic interest groups: The post-1980 Turkish experience, ed. M. Heper, 163-76. Berlin: Walter de Gruyter.

Heper, M. 1992. The 'strong state' and democracy: The Turkish case in comparative and historical perspective. In Democracy and modernity, ed. S.N. Eisenstadt, 142-63. Leiden: E.J. Brill.

Heper, M. 1994. Trials and tribulations of democracy in the third Turkish Republic. In Politics in the third Turkish Republic, ed. M. Heper and A. Evin, 231-41. Boulder, CO: Westview Press.

Heper, M. 2007. The state and Kurds in Turkey: The question of assimilation. London: Palgrave Macmillan.

Heper, M. 2009. Does secularism face a serious threat in Turkey? Comparative Studies of South America, Africa and the Middle East 29, no. 3: 411-22.

Heper, M., and N.B. Criss. 2009. The historical dictionary of Turkey. Lanham, MD: Scarecrow Press.

Heper, M., and M.S. Sancar. 1998. Is legal-rational bureaucracy a prerequisite for a rational-productive bureaucracy? The case of Turkey. Administration and Society 30, no. 2: $143-65$.

İnalcık, H. 1997. Tarihsel bağlamda sivil toplum ve tarikatlar [Civil society and religious orders in historical context]. In Küreselleşme sivil toplum ve İslam [Globalization, civil society and Islam], ed. E.F. Keyman and A.Y. Sarıbay, 74-87. Ankara: Vadi Yayınları.

Introvigne, M. 2006. Turkish religious market(s): A view based on the religious economy theory. In The emergence of a new Turkey: Democracy and the AK Party, ed. M.H. Yavuz, 23-48. Salt Lake City: University of Utah Press.

Kadıoğlu, A. 2002. Gelecekte devlet ve sivil toplum örgütlerinin işbirliğine yönelik sonuç yorumlar1 [Concluding comments concerning cooperation between the state and civil society organizations in the future]. In Devlet ve sivil toplum bağlaminda halk katılımcılığ ve sivil toplum kuruluşlar [People's participation and civil society organizations in the context of state and civil society interface], ed. K.A. Vakfi, 131-32. Ankara: Konrad Adenauer Vakfi.

Kalaycığlu, E. 2001. Turkish democracy: Patronage versus governance. Turkish Studies 2, no. 1: 54-70.

Kalaycioğlu, E. 2002. Civil society in Turkey: Continuity or change? In Turkish transformation: New century, new challenges, ed. B.W. Beeley, 59-78. Cambridgeshire: Eothen Press. 
Kalaycıŏlu, E., Ü. Ergüder, and A. Çarkoğlu. 2007. Turkish democracy today. London: I.B. Tauris.

Kaldor, M. 2003. Global civil society: An answer to war. Oxford: Blackwell.

Karpat, K.H. 1959. Turkey's politics: The transition to multi-party system. Princeton, NJ: Princeton University Press.

Karpat, K.H. 1973. An inquiry into the social foundations of nationalism in the Ottoman State: From social estates to classes, from millets to nations. Research Monograph No. 39. Princeton, NJ: Center for International Affairs, Princeton University.

Karpat, K.H. 2001. The politicization of Islam: Reconstructing identity, state, faith, and community in the late Ottoman Empire. London: Oxford University Press.

Kasaba, R. 1997. Kemalist certainties and modern ambiguities. In Rethinking modernity and national identity, ed. R. Kasaba and S. Bozdoğan, 15-37. Seattle: University of Washington Press.

Keyman, E.F., and Z. Öniş. 2007. Turkish politics in a changing world: Global dynamics and domestic transformations. Istanbul: Istanbul Bilgi University Press.

Kopeckȳ, P., and C. Mudde. 2003. Rethinking civil society. Democratization 10, no. 3: 1-14.

Mardin, Ş. 1969. Power, civil society, and culture in the Ottoman Empire. Comparative Studies in Society and History 11: 258-81.

Mardin, Ş. 1973. Center-periphery relations: A key to Turkish politics? Daedalus 102: 16990.

Mardin, S.. 1988. Freedom in an Ottoman perspective. In State, democracy and the military: Turkey in the 1980s, eds. M. Heper and A. Evin, 23-35. Berlin/New York: Walter de Gruyter.

Martindale, D. 1959. Sociological theory and the ideal types. In Symposium on sociological theory, ed. L. Gross, 57-91. Evanston, IL: Row, Petersen.

Newton, K. 2001. Trust, social capital, civil society, and democracy. International Political Science Review 22, no. 2: 201-14.

Özbudun, E. 1997. Civil society and democracy in Turkey. In Civil society and democracy and the Muslim world, ed. E. Özdalga and S. Persson, 85-92. Istanbul: Swedish Research Institute.

Özbudun, E., and S. Yazıc1. 2004. Democratization reforms in Turkey (1993-2004). Istanbul: TESEV.

Rodrique, A. 1995. Difference and tolerance in the Ottoman Empire. (Interview by Nancy Reynolds). Stanford Humanities Review 5, no. 1: 81-90.

Sarıbay, A.Y. 1997. Türkiye'de demokrasi ve sivil toplum [Democracy and civil society in Turkey]. In Küreselleşme sivil toplum ve İslam [Globalization, civil society and Islam], ed. E.F. Keyman and A.Y. Sarıbay, 88-110. Ankara: Vadi Yayınları.

Sedgwick, M.J. 2000. Sufism: The essentials. Cairo: The American University in Cairo Press.

Seligman, A.B. 1992. The idea of civil society. New York: Free Press.

Sevindi, N. 2008. Contemporary Islamic conversations: M. Fethullah Gülen on Turkey, Islam, and the West, ed. (with an Introduction by) I.M. Abu-Rabi, Trans. A.T. Antepli. Albany: State University of New York.

Shankland, D. 1999. Islam and society in Turkey. Cambridgeshire: Eothen Press.

Shils, E. 1997a. Civility and civil society: Good manners between persons and concern for the common good in public affairs. The virtue of civility: Selected essays on liberalism, tradition, and civil society, ed. S. Grosby, 63-102. Indianapolis, IN: Liberty Fund.

Shils, E. 1997b. The virtue of civility. In The virtue of civility: Selected essays on liberalism, tradition, and civil society, ed. S. Grosby, 320-55. Indianapolis, IN: Liberty Fund.

Şimşek, S. 2004. The transformation of civil society in Turkey: From quantity to quality. Turkish Studies 5, no. 3: 46-74.

Smolar, A. 1996. Civil society after communism: From opposition to atomization. Journal of Democracy 7, no. 1: 24-38.

Tocci, N. 2005. Europeanization in Turkey: Trigger or anchor for reform? South European Society and Politics 10, no. 1: 73-83.

Toprak, B. 1995. Civil society in Turkey. In Civil society in the Middle East, ed. A.R. Norton, Vol. 2, 87-118. Leiden: E.J. Brill.

Tosun, G.E. 2001. Demokratikleşme perspektifinden devlet-sivil toplum ilişkisi [State-civil society relationship from the perspective of democracy]. Istanbul: Alfa Yayınlar1. 
Turner, B.S. 2000. Islam, civil society, and citizenship: Reflections on the sociology of citizenship and Islamic studies. In Citizenship and the state in the Middle East: Approaches and applications, ed. N.A. Butenschon, U. Davis, and M. Hassasian, 28-48. Syracuse, NY: Syracuse University Press.

Tusalem, R.F. 2007. A boon or a bane? The role of civil society in third - and fourth - wave democracies. International Political Science Review 28, no. 3: 361-86.

Uhlin, A. 2009. Which characteristics of civil society organizations support what aspects of democracy? Evidence from post-communist Latvia. International Political Science Review 30, no. 3: 271-94.

Walzer, M. 1992. The civil society argument. In Dimensions of radical democracy: Pluralism, citizenship, community, ed. C. Mouffe, 89-107. London: Verso.

Weber, M. 1968. Economy and society: An outline of interpretative sociology. Compiled by Guenther Roth and Claus Wittich. New York: Bedminster Press.

Weigle, M.A., and J. Butterfield. 1992. Civil society in reforming communist regimes: The logic of emergence. Comparative Politics 25, no. 1: 1-23.

Yavuz, M.H. 2003. Islamic political identity in Turkey. New York: Oxford University Press.

Yavuz, M.H. 2009. Secularism and Muslim democracy in Turkey. Cambridge: Cambridge University Press. 